\title{
The Influence Of Ethical Leadership On Managerial Performance: Mediating Effects Of Mindfulness And Corporate Social Responsibility
}

John J. Williams, Singapore Management University, Singapore

Alfred E. Seaman, Humber Institute of Technology \& Advanced Learning, Canada

\begin{abstract}
In a continuing world of corporate misdeeds and unscrupulous decision making, much of the management and academic literatures points to the incomplete knowledge of the consequences of ethics leadership. One of the bastions of ethics gatekeeping in the firm is the CFO but remarkably scant information can be found on their perceptions concerning ethics leadership. This study addresses this void by examining mindfulness and corporate social responsibility (CSR) initiatives as new mediating linkages in comprehending the influence of ethics leadership on managerial performance. Findings reveal that ethical leadership is positively associated with CSR initiatives which, in turn, operate to enhance managerial performance. Simultaneously, ethical leadership manifests a significant positive relationship with mindfulness but, surprisingly, there is no corresponding relationship with managerial performance. Instead, mindfulness indirectly influences managerial performance through the intervening effects on CSR initiatives. These findings suggest that firms can acquire better managerial performance by focusing efforts on CSR strategies, bringing cognitive processes of mindfulness to bear on these actions, and grooming ethics leadership. In addition, the results offer researchers new relationships to model in the leadership domain.
\end{abstract}

Keywords: Ethical Leadership; Managerial Performance; Mindfulness; Corporate Social Responsibility; Path Analysis

\section{INTRODUCTION}

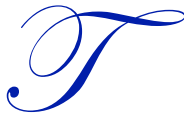

he idea of leadership dates back to the time of Aristotle but the notion of ethical leadership is a more contemporary phenomenon, with implications for virtuous actions and ethical behavior within the workplace. Leading experts in the field (Brown \& Treviño, 2006; Treviño, Hartman, \& Brown, 2000) posit that the antecedents and outcomes of ethical leadership remain largely unexplored. In contrast to the historical focus on the leader in isolation, more recent research has been devoted to the leader-follower perspective (Bass, 1990; Burns, 1978; Greenleaf, 1977, 1979) because followers tend to mimic successful leaders (Guillen \& Gonzalez, 2001), comply with higher level objectives, and potentially increase their own performance as a consequence (Drucker, 1986). The general consensus is that more ethics in the leadership function will enhance these qualities as well as contribute to possible trickle-down effects from the leader to subordinates (Mayer, Kuenzi, Greenbaum, Bardes, \& Salvadore, 2009; Ruiz, Ruiz, \& Martínez, 2011) which, in turn, will enhance job outcomes and support a more effective practiced leadership (Ciulla, 2004). In an effort to gain better understanding, more recent discussion in the ethics leadership literature has concentrated on the moral dimension (Ruiz et al., 2011).

Treviño et al. (2000) \& Brown et al. (2005) surmise that two pillars - one based on a morally good person and the other based on a morally good manager - are prerequisite for creating an ethical leader and, therefore, reaping performance benefits from this stature. The altruistic facet imbues character attributes reflecting caring, integrity, trustworthiness, honesty, empathy, and listening to others (Ruiz et al., 2011), which are synchronous with being a morally good person and are grounded in transformational leadership theory (Avolio \& Garnder, 2005; Bass, 1985; 
Burns, 1978; Kanungo \& Mendonca, 1996). Alternatively, Brown et al. (2005) rely on transactional leadership theory (Bass, 1985; Burns, 1978) to specify behavioral conditions for being a morally good manager: the leader's ethical behavior must be visible, ethical/unethical behavior must be praised/acknowledged within the context of standardized routines, and the prominence of ethical values that enshroud managerial activity and decision making must be publicized. Other aspects of leadership theory are based on social learning theory (Bandura, 1986) where people tend to covet and mimic enticing role models in their learning process, and social exchange theory (Avey, Wernsing, \& Palanski, 2012; Emerson, 1976; Kacmar, Bachrach, Harris, \& Zivnuska, 2011; Mayer et al., 2009) where people are pulled together by mutual exchanges that benefit one another.

Recent empirical research has used the moral perspective underpinning ethics leadership to explain how it determines performance outcomes that include turnover intentions, organizational citizenship behavior, job satisfaction, and task performance, as well as several mediating and moderating effects that influence these potential relationships (Avey, Palanski, \& Walumbwa, 2011; Avey et al, 2012; Kacmar et al., 2011; Mayer et al. 2009; Piccolo, Greenbaum, Den Hartog, \& Folger, 2010; Ruiz et al., 2011; Shin, 2012; Toor \& Ofori, 2009). Undeniably, these are admirable benefits for practitioners; in fact, it would not seem unreasonable to speculate that these types of performance outcomes would also favor improved managerial performance. Oddly enough, however, the relationship between ethics leadership and managerial performance at an executive level, such as the CFO, has never been empirically examined to our knowledge. Furthermore, to the extent that the moral dimension of leadership is emphasized, we argue, and demonstrate, that mindfulness and corporate social responsibility (CSR) are two processes that positively mediate the ethical leadership/managerial performance link because of their grounding in virtuous behavior, whether from the manager or from the person perspective.

The purpose of this paper, therefore, is to examine managerial performance through the moral lens of the CFO enacting an ethical leadership posture, without explicitly considering the trickle-down effects to one or more followers. The rationale is that if there are assumed beneficial performance outcomes for followers, as vehemently asserted in the academic and practice literatures (Bandura, 1986; Bass, 1990; Mayer, 2009, 2012), then genuine moral qualities held by the leader should also carry performance benefits in her/his corresponding work role. Despite empirical research directed at the effects of ethics leadership on CSR (Waldman, Siegel, \& Javidan, 2006), this perspective has scarcely been explored and the effects of ethical leadership on mindfulness have been bypassed completely.

Also, CSR is relevant because social initiatives by the firm, supported by executive actions from the CFO, manifest potential decision making behavior that followers can admire, role model, and understand through communication efforts (Brown \& Treviño, 2006). In short, these attributes render the worksite a better place to operate and enable more effective managerial routines. Likewise, mindfulness is linked to morality simply because behavior that attempts to avoid failures, overcome disabling errors, create team minds, act thinkingly, promote thought leadership, and tries to enhance reliability (Langer, 1989, 1997; Rochlin, 1989, 1993; Westrum, 1992; Weick, Sutcliffe, \& Obstfeld, 1999) is ethically endorsable by everyone. To summarize, emphasizing CSR initiatives leans towards the moral person dimension of ethical leadership whereas mindfulness conveys more of the moral manager dimension of ethical leadership. Concomitantly, both of these mediating effects are suggestive of virtuous ethical leadership qualities in that each one involves a principled decision maker who cares about people and the broader society (Brown \& Treviño, 2006; Treviño et al., 2000).

We continue this paper in the next section by reviewing the salient literature and then developing corresponding hypotheses. This is followed by two sections detailing the method and the research findings, respectively. Implications of the results are discussed in the penultimate discussion section while limitations are noted and potential follow-up research is mentioned in the concluding section.

\section{BACKGROUND}

The conceptual model tested in this study is displayed in Figure 1. It investigates the influence of ethical leadership on managerial performance through the intervening effects of mindfulness and CSR initiatives. The essence of these constructs is briefly discussed below followed by their hypothesized relationships. 
Figure 1. Hypothesized model of the mediating effects of mindfulness and CSR in the ethics leadership/managerial performance link

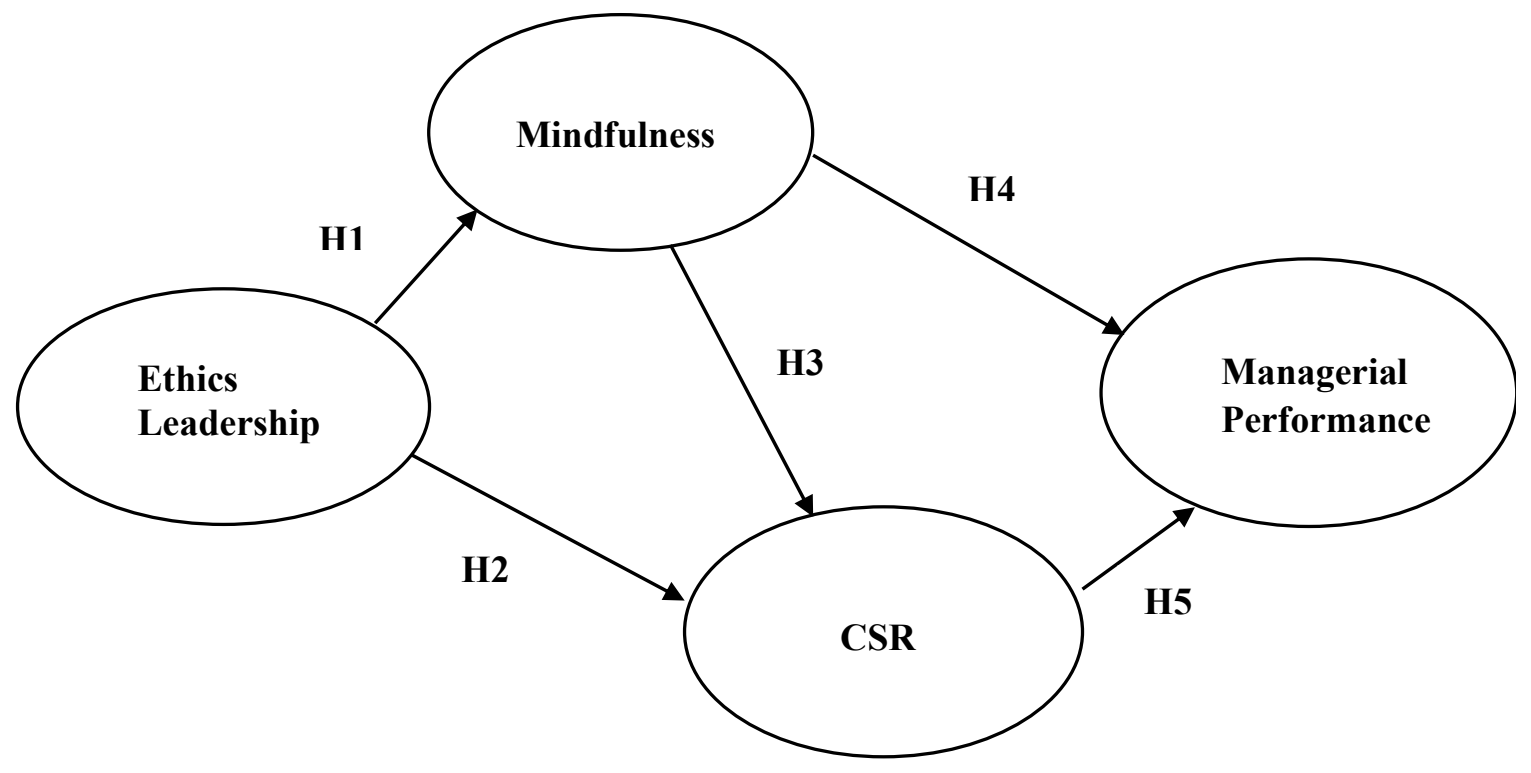

\section{Ethical Leadership}

There is a strong consensus among researchers (Avey et al., 2011; Avey et al. 2012; Kacmar et al., Mayer, 2009; Piccolo et al., 2010; Ruiz et al., 2011; Shin, 2012; Toor \& Ofori, 2009) that ethical leadership is the "demonstration of normatively appropriate conduct through personal actions and interpersonal relationships, and the promotion of such conduct to followers through two-way communication, reinforcement, and decision making" (Brown, Treviño, $\&$ Harrison, 2005, p. 120). Although there are traces of several theories underlying this definition, its substance is mainly anchored in social learning theory (Bandura, 1977). Inductive research (Brown et al., 2005; Treviño et al., 2000) uncovered the moral person aspect of leadership which is built on a leader's personal characteristics and altruistic tendencies. A second facet, labeled the moral manager, features the specific intention by the leader to influence followers' ethical and unethical actions. This tends to be accomplished structurally through communication of desirable values and behavior, role modeling ethical conduct, and establishing reward and punishment control systems.

Social learning theory (Bandura, 1986) essentially explains why certain situational factors are linked to these moral attributes of the leader and are thus able to influence followers' perceptions of a leader as being ethical. First, individuals learn by copying and emulating the actions, values, and attitudes of legitimate role models. We assume that CFOs are champions of ethical values in the firm and represent a hallmark of instigating ethical systems through their architecture of codes of conduct and control systems that monitor ethical and unethical behavior. Secondly, CFOs also manifest the requisite power and status that Bandura (1986) claims is vital to be a credible ethical leader. However, these two attributes are not sufficient; legitimate ethical leaders must also be trustworthy, caring, and fair to garner attention. Thirdly, the ethics message must be made salient through control mechanisms that highlight rewards and punishment, various types of reporting channels that could include CSR initiatives, and transparency over the use of important resources. Finally, vicarious learning (Brown \& Treviño, 2006) is assumed to be fundamental for learning about ethical or unethical behavior. This means that learning occurs by observing other peoples' actions and behavior, noting the outcomes, and garnering the benefits - thus implicating the role of mindfulness.

\section{Mindfulness}

Following Langer (1989, 1997), Rochlin (1989), and Weick et al. (1999), mindfulness represents a capacity for action to discover and manage unexpected events based on concepts of anticipation and containment. These concepts deal with cognitive processes that focus on failures, reluctance to simplify interpretations, sensitivity to 
operations, commitment to resilience, and under-specification of authority structures. While much of the literature on mindfulness is anchored in the concept of high reliability organizations (e.g., HROs such as aircraft carriers, power grids, or nuclear submarines), the concept is applicable anywhere in the organization given that a particular event could arise (even with ethical overtones) for which precautions were taken, but failure occurs, with negative repercussions for an individual's job and career (Weick et al., 1999; Weick \& Sutcliffe, 2001). Because HROs worry about failures, they endorse and reward the reporting of errors, do not see safety in near misses, increase their alertness after success, avoid complacency, and actually expand search believing that success will not repeat itself (March, Sproull, \& Tamuz, 1991; Sitkin, 1992).

A second quality of mindful anticipation is the ability to increase the number of precautions enacted (Roth, 1997), socialize people to heed more (Xiao, Milgram, \& Doyle, 1997), and develop interpersonal skills that are respectful yet wary of other peoples' competence in an effort to arrest failure (Weick \& Sutcliffe, 2001). Mindful anticipation is also crafted by creating sensitivity to the 'big picture' of operations through face-to-face communication, bypassing the conventional hierarchy, and moving problems toward expertise (Roberts, Stout, \& Halpern, 1994). When failure transpires, organizations need to cope with the problem and contain it. Mindful containment is facilitated by resilience and under-specification of the power structure in the organization. While anticipation tries to prevent damage and failure from occurring, resilience involves the capacity to cope with present surprises and learning to recover or bounce back from setbacks (Wildavsky, 1991). Finally, the ability to blend decision making structures and authority structures rapidly allows individuals to manifest bricolage, what Weick (1990) describes as the competency to recombine past experience to deal with "never seen before" surprises.

\section{The Nature of CSR Initiatives}

For McWilliams \& Siegel (2001), CSR actions are voluntarily aimed at promoting some social good that transcends the legal interests of the firm and its shareholders. A firm's CSR actions tend to operate as signals to all stakeholders - social investing according to Waddock (2001) - in an effort to establish social and reputational capital (Fombrun, Gardberg, \& Barnett, 2000). Social exchange theory (Emerson, 1976) suggests that CSR initiatives directed at stakeholders external to the organization are inclined to encourage prestige-based perceptions (Ashforth \& Mael, 1989). This is often the case for consumers' attitudes about a particular firm and how they rank various products and/or services (Luo \& Bhattacharya, 2006; Martin et al., 2009). Similar reasoning applies to suppliers' attitudes about a firm as well. However, CSR actions focused on employees result in respect-based perceptions (Farooq et al., 2014) that influence attitudes. Because CFO perceptions constitute this study's data set, we adapt Glavis \& Godwin's (2013, p. 17) definition of CSR derived from Waddock (2004) and frame it in the singular: "The perception a stakeholder of an organization holds of the impact of a company's strategies and operating practices on the well-being of all its key stakeholders and the natural environment."

\section{HYPOTHESES DEVELOPMENT}

\section{The Influence of Ethical Leadership on Mindfulness}

Within the business ethics literature, moral awareness (Jones, 1991; Rest, 1996) plays a primary role in ethical leadership because it initially triggers the moral context signifying an issue of moral content. However, moral intensity is the critical factor underpinning ethical awareness in two respects. One is the severity of the consequences associated with the decision while the other is the presence of strong ethical norms pertaining to the decision (Butterfield, Treviño, \& Weaver, 2000; Frey, 2000; May \& Pauli, 2002). Social learning theory warns that situations become socially salient when potential harm arises which draws the leader's attention. We posit that this awareness is precisely what drives cognitive processes of mindful anticipation. If the scale of consequences demand the leader' attention, then $\mathrm{s}(\mathrm{he})$ is more sensitive to the decision at hand, more alert to alternatives, and may possibly enact more precautions going forward. Therefore, morally intense predicaments heighten the leader's focus. These all funnel into, and augment, mindful interacting. Thus, the following hypothesis is proposed:

H1: Ethical leadership has a positive relationship with mindfulness. 


\section{The Influence of Ethical Leadership on CSR}

A recent approach in leadership theory is the integration of micro-level behavior, such as that manifested by the CFO for example, and macro-level phenomena such as CSR activities (House, Rousseau, \& Thomas-Hunt, 1995; Waldman, Siegel, \& Javidan, 2006). This is commonly referred to as transformational leadership, firmly advocated by Bass $(1985,1998)$, and it has considerable overlap with ethical leadership (Brown \& Treviño, 2006). In fact, Brown \& Treviño (2006) insist that the two theories are virtually the same in terms of altruism, ethical decisionmaking, integrity, and role modeling. Bass \& Steidlmeier (1999) suggest that qualities of transformational leadership extend to the larger community, thus "implying a potential connection to CSR (Waldman et al., 2006, p. 1706). More relevant to the current argument, Bass \& Steidlmeier (1999) suggest that leaders, particularly charismatic leaders, achieve higher levels of moral development which becomes directed at maintaining the social good. Waldman et al. (2006) cite Mendonca (2001, p. 1707) who argues that transformational leadership can be rooted in solid ethical values that are guided by "morally altruistic principles." Therefore, the moral visions of ethical leadership should be in harmony with the demands of multiple CSR stakeholders. Thus, such reasoning assumes that charisma is transformed into virtuous leadership which, in turn, engenders CSR in its wider social dimension (Waldman et al., 2006). Thus, the following hypothesis is proposed:

H2: Ethical leadership has a positive relationship with CSR.

\section{The Influence of Mindfulness on CSR}

We started with the observation that ethical leadership drives mindfulness and CSR, the former anchored in the moral manager and the latter entrenched in the moral person. Indirectly, the literature suggests that the two can merge within the notion of a mindful leader to influence CSR. This happens through what Bass (1985) termed intellectual stimulation - a third child of ethical leadership - steered towards transforming values and beliefs, particularly related to problem awareness. It seems that the approach is based on challenging old assumptions and beliefs so as to comprehend more complexity, more interconnections, stay tuned to complicated problems for longer, and free up slack resources. Waldman et al. (2006) refer to Wortman (1982), and more recently Boal \& Hooijberg (2001), who suggest that top-level leaders in the organization need to engage in mindful processes that evaluate opportunities and threats in the broader external environment. All of these cognitive aspects appear remarkably similar, if not identical, to the cognitive processes overarching mindfulness.

Another concept emerging in the leadership literature is conceptual capacity which also seems to overlap processes of mindfulness to a considerable extent. It deals with constructing visions and insights, unconstrained by standard routines, geared towards understanding complex problems before errors and failures occur in the system (Lewis \& Jacobs, 1992). Waldman et al. (2006, p. 1709) conjecture that "intellectually stimulating leaders will use conceptual capacity to scan and think broadly about the environmental context and the manner in which a wide variety of organizational stakeholders may be served." This comprehension occurs through the development of complex mental maps, competitive advantage, tightly coupled external conditions, and "... success in such an environment requires strong relationships with a variety of key stakeholders, as well as a perspective that includes CSR."

Once again, these views on leadership processes firmly resemble concepts that describe the types of cognitive processes that underpin mindfulness. The difference between the two is that the language of the leadership literature is couched in terms of success whereas mindfulness explicitly focuses on the prevention, capability to discover problems, and containment of errors or failures - the antithesis of success. To the extent that overlooking CSR initiatives or abusing CSR opportunities constitute a failure with dire consequences for the firm, then the linkage between mindfulness and CSR is important. We posit that cognitive leadership qualities that focus on all stakeholders, including those internal to the firm, are easily assimilated under the umbrella of cognitive mindfulness processes described above. Thus, the following hypothesis is proposed:

H3: Mindfulness has a positive relationship with CSR. 


\section{The Influence of Mindfulness on Managerial Performance}

Managerial performance for the CFO extends to a variety of functions (Brownell \& McInnes, 1986) which include responsibility over planning, coordinating activities, assessing and managing risk, interpreting and reporting required information, providing internal control, utilizing resources effectively, and generally reducing errors and failure in the system to ensure "effective and efficient practices" (IFAC, 2009, p. 6). Mindfulness potentially facilitates these tasks because of its emphasis on detecting errors, trying to avoid failures of any kind, and enabling adaptive learning. It also despises complacency and simplification which increase risk and possibly hampers the coordination of activities. In citing the work of Roth (1997), Weick et al. (1999) note that sensitivity to operations demands continual updates and monitoring the limitations of preplanned procedures. These behaviors enhance internal control, support the effective use of resources, and lead to better coordination. When these processes of anticipation are combined with mindful containment, the likelihood of maintaining or enhancing performance is improved. Thus, the following hypothesis is proposed:

H4: Mindfulness has a positive relationship with managerial performance.

\section{The Influence of CSR on Managerial Performance}

The reach of CSR initiatives and programs extends to stakeholders that are external and internal to the organization. Much of the literature appeals to social identity theory (Ashforth \& Mael, 1989) to explain how organizational members, such as employees for example, create a self-concept that hinges on the image of the firm. Studies show that organization involvement in social causes tends to improve this image (Hess, Rogovsky, \& Dunfee, 2002; Riordan, Gatewood, \& Bill, 1997) and the literature affirms that this effect can extend to any stakeholder group (Dutton, Dukerich, \& Harquail, 1994). Empirical research reveals positive correlations between the image of the firm and social actions for consumer groups (Brown \& Dacin, 1997) and job seekers' preferences for socially-valued firm characteristics (Albinger \& Freeman, 2000; Greening \& Turban, 2000). This discovery is deemed important to organizations because these outcomes are related to other work attitudes, such as job satisfaction which, in turn, influence organizational commitment (Peterson, 2004), corporate citizenship (Maignan et al., 1999), reduce conflict, and lower turnover rates (Wood \& Jones, 1995). Referencing job satisfaction alone, Morgeson and Humphrey (2006) indicated their surprise in finding social factors even more important than compensation or the nature of the job.

We conjecture that all of these benefits, which appear to flow from social investments by the firm to multiple stakeholders, culminate in expediting the sort of CFO managerial domain envisioned by Mintzberg $(1973,1975)$. For example, lower turnover rates and more favourable employee job attitudes contribute to better planning and coordinating activities for forecasting and prioritizing work; guiding, directing, and motivating subordinates through constructive criticism and feedback; and training, coaching, and developing subordinates. Additionally, an enhanced firm image from social endeavors facilitates friendly communication, representing the organization's best side to the public, handling crises, and trouble shooting. More generally, these attributes foster cooperation throughout the organization and promote the coordination, allocation, monitoring, and control of resources (Mintzberg, 1973, 1975)

- managerial activities that CFOs dutifully embrace. Thus, the following hypothesis is proposed:

H5: CSR initiatives has a positive relationship with managerial performance.

\section{METHOD}

\section{Sample and Data}

CFOs/controllers for this study were selected from the firm membership directory of the Society of Management Accountants of Canada as part of a larger web-based survey research project. This initial filter yielded 563 responses and was advantageous in several respects: it permitted membership and designation cross-referencing; it assured uniform exposure to the Society's code of professional conduct, including social and ethical values; it identified executives who manifest expert knowledge over various governance controls, ethics, value systems, and reporting; and it assured an explicit understanding of all internal and external stakeholders. Small firms (less than 
200 employees), utilities and non-profit organizations, and responses indicating less than four years in the executive position were excluded based on Murphy et al.'s (1992) finding of different ethical conduct among small and large firms, Chenhall \& Brownell (1988) and Brownell \& Dunk's (1991) concern over operating differences in these organizations, and seeking some homogeneity of experience in leading the firm's accounting and control function, respectively. This produced 168 responses of which 30 were incomplete, leaving a usable sample of 138 for analysis. Response bias was assessed by splitting the sample into two groups according to response date (Armstrong $\&$ Overton, 1977) and assessing the means and standard deviation of the measured variables in the two sub-samples. No evidence of response bias emerged from this procedure.

\section{Measures}

All measures were adapted from the literature and tailored to the setting of this study. A five-point Likert scale ranging from 1 (to a very little extent) to 5 (to a very large extent) was utilized to measure all the independent constructs. Following Mayer, Aquino, Greenbaum, \& Kuenzi, (2012) and Piccolo et al. (2010), ethical leadership was measured using Brown et al.'s (2005) ethical leadership scale (10 items) and modified for this study to garner perceptions from CFOs. Interestingly, exploratory factor analysis produced two factors. The first factor consisted of five items pertaining to the leader's traits such as trustworthiness, concern over employees, hearing what employees have to say - items remarkably close to describing a moral person. The second factor also consisted of five items dealing with ethical processes such as spending time on ethics training, modeling ethical behavior, applying a code of ethics, and monitoring ethical/unethical decisions - items that would appear to be associated with a moral manager. These two constructs served as latent variables for ethics leadership and were directly input into the structural equation model (SEM). The composite reliability for each scale was 0.91 and 0.86 , respectively, well above minimum threshold of 0.6 recommended in the literature (Bagozzi \& Yi, 1988).

Measures for mindfulness were taken directly from Williams \& Seaman (2010) who developed the scales from the extensive work of Weick \& Sutcliffe (2001). Mindfulness was constructed from five scales dealing with preoccupation with failure, reluctance to simplify, sensitivity to operations, commitment to resilience, and deference to expertise. These measures were then entered into the SEM. The overall composite reliability was 0.89 .

Similar to Zheng, Luo, \& Wang (2014), we operationalized CSR by five scales that capture the innovation of new ideas for consumers, the welfare of the firm's stakeholders, communication among stakeholders, the encouragement of learning and development among employees, and reporting social audit findings to the public. These items broadly cover both internal and external stakeholders, as recommended by Turker (2009) \& Farooq, Payaud, Merunka, \& Valette-Florence (2014), as well as the communication and reporting concerns raised by Morsing \& Schultz (2006). The five scales were directly input into the SEM and yielded a composite reliability of 0.82 .

We borrowed the instrument developed by Mahoney, Jerdee, \& Carroll (1963) and introduced to the accounting literature by Brownell \& McInnes (1986) to measure the dependent variable managerial performance using a sevenpoint Likert scale from ranging from 1 (to a very little extent) to 7 (to a very large extent). Mahoney et al. (1963) insisted that for homogenous managerial settings, and given the absence of multi-collinearity, using all eight items captures the construct of managerial performance better versus the overall rating. After diagnostic checks showed no multi-collinearity and given the setting of our sample, eight items were used as direct inputs to the SEM. The scale's composite reliability was 0.91 .

\section{RESULTS}

\section{Measures, Reliability and Validity}

Validity and reliability were assessed for all measures and these are reported in Table 1. Ethics leadership was measured by two latent variables of five items each: one referring to the moral person and the other referring to the moral manager. Confirmatory factor analysis (CFA) produced a single factor structure for the moral person dimension of ethics leadership, with item loadings ranging from 0.75 to 0.90 . CFA yielded a similarly solid factor structure for the moral manager dimension, with item loadings ranging from 0.59 to 0.82 . Mindfulness was unidimensional and CFA provided a good fit with loadings ranging from 0.68 to 0.84 . CSR was also measured by 
five items to yield a single factor, with item loadings ranging from 0.56 to 0.85 . Eight items were used to measure managerial performance which emerged as a single factor structure from CFA, with loadings ranging from 0.63 to 0.83 . Finally, the measurement model revealed that the across-construct CFA yielded an acceptable fit to the data (Schermelleh-Engel, Moosbrugger, \& Müller, 2003): $\chi_{(321)}^{2}=429.28(\mathrm{p}=0.00), \chi^{2} / \mathrm{df}=1.38$, goodness of fit index $(\mathrm{GFI})=0.82$, adjusted goodness of fit index $(\mathrm{AGFI})=0.76$, comparative fit index $(\mathrm{CFI})=0.98$, normed fit index $(\mathrm{NFI})=0.95$, non-normed fit index $(\mathrm{NNFI})=0.98$, root mean square error of approximation $(\mathrm{RMSEA})=0.05$, and root mean square residual $(\mathrm{RMR})=0.06$. CFA loadings and standard errors can also be utilized to assess convergent validity and Table 1 reveals that they were all significant (t-values $>1.96$ ). In addition to composite reliability, Table 1 shows Cronbach (1951) alpha values ranging from 0.76 to 0.89 . These are well above the generally accepted threshold of 0.70 (Bagozzi \& Yi, 1988), thus demonstrating sufficient internal consistency for each measure. ${ }^{1}$

Table 1. Reliability and Validity Assessment of the Construct Measures

\begin{tabular}{|c|c|c|c|c|c|c|}
\hline Construct & Indicator & $\begin{array}{c}\text { CFA } \\
\text { Loading }\end{array}$ & t-value* & SMC & $\begin{array}{c}\text { Cronbach } \\
\text { Alpha }\end{array}$ & $\begin{array}{l}\text { Composite } \\
\text { Reliability }\end{array}$ \\
\hline Ethics & People value trustworthiness & 0.78 & 10.97 & 0.61 & 0.86 & 0.91 \\
\hline Leadership: & BOD models ethical behavior & 0.83 & 12.25 & 0.69 & & \\
\hline \multirow[t]{3}{*}{ Moral Person } & Top management models EB & 0.90 & 14.36 & 0.81 & & \\
\hline & Front-line management models EB & 0.83 & 12.31 & 0.69 & & \\
\hline & Employees are treated fairly & 0.75 & 10.28 & 0.57 & & \\
\hline Ethics & Time is spent on ethics training & 0.59 & 7.04 & 0.31 & 0.84 & 0.86 \\
\hline Leadership: & Code of ethics serves as guidelines & 0.80 & 11.31 & 0.64 & & \\
\hline \multirow[t]{3}{*}{ Moral Manager } & Structure adjusted for ethics & 0.65 & 8.73 & 0.42 & & \\
\hline & Controls over executive decisions & 0.82 & 11.52 & 0.67 & & \\
\hline & Stated ethics match each employee & 0.82 & 11.62 & 0.67 & & \\
\hline \multirow[t]{5}{*}{ Mindfulness } & Avoid failure & 0.68 & 8.82 & 0.46 & 0.88 & 0.89 \\
\hline & No simplification & 0.81 & 11.32 & 0.66 & & \\
\hline & Sensitivity & 0.76 & 10.36 & 0.58 & & \\
\hline & Resilience & 0.80 & 11.26 & 0.64 & & \\
\hline & Defer to expertise & 0.84 & 12.13 & 0.71 & & \\
\hline Corporate & CSR to social stakeholders & 0.59 & 7.42 & 0.35 & 0.76 & 0.82 \\
\hline Social & CSR to employees & 0.82 & 11.58 & 0.67 & & \\
\hline \multirow[t]{3}{*}{ Responsibility } & CSR to consumers & 0.85 & 12.20 & 0.72 & & \\
\hline & CSR to government & 0.67 & 9.06 & 0.45 & & \\
\hline & CSR to social reporting & 0.56 & 6.37 & 0.25 & & \\
\hline Managerial & Planning & 0.75 & 10.39 & 0.56 & 0.89 & 0.91 \\
\hline \multirow[t]{7}{*}{ Performance } & Investigating & 0.63 & 7.70 & 0.40 & & \\
\hline & Coordinating & 0.83 & 11.46 & 0.69 & & \\
\hline & Evaluating & 0.72 & 9.69 & 0.52 & & \\
\hline & Supervising & 0.70 & 9.08 & 0.49 & & \\
\hline & Staffing & 0.75 & 10.45 & 0.56 & & \\
\hline & Negotiating & 0.64 & 8.31 & 0.41 & & \\
\hline & Representing & 0.72 & 9.30 & 0.52 & & \\
\hline
\end{tabular}

\section{Tests of Hypotheses}

SEM was utilized to test the conceptual model in Figure 1. The fit statistics shown in Table 2 suggest an acceptable fit to the data. Hypothesis $\mathrm{H} 1$ states that ethics leadership is positively related to mindfulness and the findings reported in Table 2 fully support this relationship $(\gamma=0.89 ; \mathrm{t}=9.62)$. Hypothesis $\mathrm{H} 2$ predicts that ethics leadership is positively linked to CSR. The results $(\gamma=0.63 ; \mathrm{t}=4.76)$ affirm this relationship. Hypothesis $\mathrm{H} 3$, meanwhile, asserts that mindfulness leads to increased CSR and, once again, the findings confirm this relationship $(\gamma=0.37 ; \mathrm{t}=$ 2.91). However, the expected linkage in hypothesis H4 suggesting that mindfulness enhances managerial performance is not supported $(\gamma=\mathrm{n} / \mathrm{s} ; \mathrm{t}=1.28)$ and, therefore, this hypothesis must be rejected. Finally, hypothesis 
$\mathrm{H} 5$ posits that more CSR initiatives leads to increased managerial performance and the findings $(\gamma=0.42 ; \mathrm{t}=4.51)$ support this relationship.

Table 2. Structural Equation Model Results

\begin{tabular}{|c|c|c|c|}
\hline Hypothesis & Standardized Estimate & $t$-value & Test Result \\
\hline Ethics leadership $\rightarrow$ mindfulness (H1) & 0.89 & $9.62 * *$ & Supported \\
\hline Ethics leadership $\rightarrow$ CSR (H2) & 0.63 & $4.76^{* *}$ & Supported \\
\hline Mindfulness $\rightarrow$ CSR (H3) & 0.37 & $2.91 *$ & Supported \\
\hline Mindfulness $\rightarrow$ managerial performance $(\mathrm{H} 4)$ & $\mathrm{n} / \mathrm{s}$ & $\mathrm{n} / \mathrm{s}$ & Not supported \\
\hline $\mathrm{CSR} \rightarrow$ managerial performance (H5) & 0.42 & $4.51 * *$ & Supported \\
\hline
\end{tabular}

\section{Additional Analyses}

Obtaining measures of the variables under study from cross-section survey data featuring the same respondent and the same research instrument (Podsakoff, MacKenzie, Lee, \& Podsakoff, 2003) may give rise to a problem of common method variance (CMV). Following Harman (1967), all study variables were factor analyzed using unrotated principle component analysis. This produced four factors with eigenvalues greater than one, accounting for nearly 70 percent of the total variance. The first factor contributed less than the majority of the total variance explained, effectively negating the assumption of a single factor. To verify this result, a CFA was constrained to one factor to assess the model fit; as expected, the model statistics were poor. These procedures suggest that CMV is not a serious threat in the present study and is not likely to degrade the interpretation of the results.

In addition, the research model presented in Figure 1 did not include any direct link from ethics leadership to managerial performance because there was no underlying rationale to justify a direct relationship. Nonetheless, to confirm the above findings from our research model, the path from ethics leadership to managerial performance was modelled and, as anticipated, no significant path emerged.

\section{DISCUSSION}

This study examined the mediating effects of mindfulness and CSR initiatives in the linkage of ethics leadership and managerial performance based on CFO perceptions. We discovered that both intervening variables have a significant positive relationship with ethics leadership. However, only CSR initiatives produced a significant positive association with managerial performance; unexpectedly, mindfulness did not have a significant direct impact on managerial performance. Instead, mindfulness operates indirectly to positively increase CSR initiatives which, in turn, serves to enhance managerial performance.

Relying on the dual themes elaborated upon earlier in the paper, it appears that while qualities signifying the moral manager space of CFOs correspond to cognitive processes that envelop and heighten mindfulness, the consequences are not transferred to better managerial performance. One explanation may lie in the nature of Thompson's (1967) departmental design categories. He postulated that controller's departments serve dual perspectives - boundary spanning activities that are more externally focused and reciprocal services involving the internal technical core. The sheer magnitude of control system routines, interactions, transactions, and communications involving the technical core that are repeated, duplicated, recast, and reinforced almost daily, arguably far outweigh external interchanges.

In short, the firm's internal control system grapples with extreme rigidities, reliabilities are high, and incidences of failure are presumable too infrequent or miniscule to make a difference in the CFO's operating platform. Thus, there is little capacity in this work role for the moral manager aspects of mindfulness to influence performance; any increase in mindfulness simply serves as confirmatory ethical leadership qualities but not sufficient to improve managerial performance. For example, ensuring that the code of ethical conduct is honored in the organization does little to assist the planning, organizing or prioritizing of work for the CFO. Moreover, supervision, performance reviews, and standardized procedures that represent the organization to customers and the public tend to be 
perfunctory because they draw upon historical aspects of control that are routinely repeated, thus squeezing out any benefits of more mindfulness improving operating performance.

Instead, it appears that the moral manager dimension in ethical leadership surfaces more strongly through the positive indirect intervening effects of mindfulness on CSR initiatives, and then on to positively benefit managerial performance. Mindfulness, it seems, contributes to a domain of CSR initiatives and actions where there are less routinized and well-developed situations embracing various stakeholders (Waldman et al., 2006). In other words, cognitive processes involving anticipation and resilience are more adaptable, useful, and visible in less structured environments which would include the domain of CSR initiatives. It is well understood that the reach of social initiatives is diverse and unstructured (Panwar, Rinne, Hansen, \& Juslin, 2006; Perez, \& Rodríguez del Bosque, 2013) - a perfect place for mindfulness to thrive in conjunction with the moral person attributes underpinning CSR initiatives and, together, enhancing managerial performance.

This interpretation is consistent with Bass' (1985) reference to intellectual stimulation which deals with leader actions focused on change in problem awareness and arousal, including beliefs and values. Wortman (1982) emphasized the importance of executives becoming engaged in conceptualizing the firm in its broader environmental context and, hence, the linkage to CSR. Waldman et al. (2006) expand further on the concept of conceptual capacity in ethics leadership and the ability to process information pertinent to the environment. In citing the work of Lewis \& Jacobs (1992), Waldman et al. (2006, p. 1710) note that conceptual capacity allows ethical leaders to have "insight and construct visions ... using their own judgment processes unconstrained by the boundaries, values, or points of view of others." Moreover, and critical to this paper, such leaders display "strong relationships with a variety of key stakeholders, as well as a perspective that includes CSR" (Waldman et al., 2006, p. 1710). Based on our results, it would seem that these characteristic hallmarks of CSR actions are reinforced by cognitive processes that underpin mindfulness.

\section{Implications for Research and Practice}

This study offers several theoretical implications. Based on social learning theory and transformational leadership theory, this study attempts to explain the virtuous leadership attributes that feed multiple CSR initiatives. Although the literature is particularly silent on the role of mindfulness and ethical leadership, our findings affirm that mindfulness serves an important intervening function in terms of channeling ethical leadership qualities to enhanced CSR initiatives. To our knowledge, no other study has examined this relationship. Furthermore, this study has introduced managerial performance as an important outcome variable that is influenced by the interplay of ethical leadership and CSR, apart from emphasis on the more popular variables of job satisfaction (Berstein \& Nash, 2008), commitment (Farooq et al., 2014), employee turnover (Peterson, 2004), corporate citizenship (Glavis \& Piderit, 2009; Waddock, 2004), and organizational identification (Glavis \& Godwin, 2013). To summarize, our study provides a comprehensive framework for constructing future studies to expand our understanding of the linkage between ethical leadership and performance.

Several managerial implications are available as well. Much of the contemporary research on ethics leadership is directed at the influence of followers. Our findings reveal that ethical leadership has positive prosocial implications that emanate solely from the leader, apart from any trickle-down or role model effects on lower level employees. CFOs are in a strategically powerful position to influence a broad spectrum of social opportunities for the firm, with the added realization that their decisions and actions can potentially benefit their job performance. As argued earlier, this works because, to the extent that CFOs are seen as increasing CSR initiatives generally, organization members tend to perceive fair and caring treatment as do external stakeholders. Nearly a half-century ago, Blau (1964, p. 94) commented that "social exchange tends to engender feelings of personal obligation, gratitude and trust." More recent arguments from researchers (Dirks \& Ferrin, 2002; Brown \& Treviño, 2006) suggest that all stakeholders should be willing to exceed expectations in any exchanges with ethical leaders. We anticipated that CSR initiatives would positively influence managerial performance and produced evidence accordingly; organizations, therefore, should not underestimate the performance benefits emerging from the interconnection of CSR and ethics leadership. Of course, nurturing mindfulness as the 'third child' in this collective relationship should be encouraged. 


\section{LIMITATIONS AND FUTURE RESEARCH}

The usual caveats that accompany exploratory behavioral research in general are acknowledged. Also, limitations of using data from the internet (AAPOR, 2013) and various restrictions with the cross-sectional survey method (Bowen $\&$ Wiesema, 1999) are noted. The decision to apply direct filters to obtain the sample precluded responses from other individuals who did not meet our status requirements and this certainly curbed the sample size. Moreover, we concentrated on perceptions of qualified CFOs largely due to their common professional and institutional backgrounds. It is possible, though, that our professional and tenure constraints were too severe; however, the sample was geographically dispersed across numerous organizations spanning multiple industries.

In terms of future research, we concentrated on a particular brand of leadership but there are other dimensions, such as charismatic leadership and transformational leadership (Avolio \& Gardner, 2005), which may have important linkages to mindfulness and CSR. The relationship of ethics leadership and CSR is most likely more complex than we have envisioned in the present paper. Depending on how control systems engage both ethical behavior and CSR policies, measures of these variables may need to be altered to capture the proper attributes. For example, there are diverse measures of CSR throughout the literature. Some research scholars focus on instrumental aspects of CSR (McWilliams et al., 2006) which adhere to firm profitability or personal benefits. In other research (Waldman et al., 2006), CSR measures are differentiated in terms of strategic issues versus social issues. Therefore, studies could easily integrate constructs from the present study with new and/or modified variables to examine a more complex path model.

The data base for this study relied on CFO perceptions and there may be a tendency to question the tradeoff of quantitative as opposed to qualitative measures on some, if not all, of the measured variables. However, recent research (Glavis \& Godwin, 2013, p. 16) argues that “... an employee's perception of what CSR behaviors their organization is - or is not - engaged in is perhaps just as important to understand as reality." We submit that perceptions are equally important in assessing the other variables examined in this study. Glavis \& Godwin (2013) further cite the seminal work of Bargh \& Burrows (1996) who offered strong evidence in support of the perceptionbehavior link - simply observing someone else's behavior increased the de facto behavior of that person. Future research, therefore, can build on this understanding to extend the relationships analyzed in the current study.

Also, future research could consider the perspective of different executives, such as the CEO or select members of the board of directors, and undertake a comparative analysis to provide a richer understanding of linkages, direct and indirect. No doubt differences would arise since the philosophy, training, and corporate actions among these players are essentially different. In the same vein, lower level managers could be targeted and comparisons undertaken across functionally different units in the organization. In each of these cases, it is possible to adopt a cross-sectional approach or to revert to case study designs for in-depth understanding.

\section{AUTHOR INFORMATION}

Dr. Williams has been a Professor of Accounting at the University of Alberta, Canada; University of Nairobi, Kenya; Queen's University, Canada; Nanyang Technological University, Singapore; and is currently a Practice Associate Professor in the School of Accountancy, Singapore Management University, Singapore. He has consulted internationally and conducted extensive research on management accounting control systems, with publications in Accounting, Organizations and Society, Behavioral Research in Accounting, California Management Review, Contemporary Accounting Research, Journal of Accounting Historians, Journal of Applied Business Research, Management Accounting Research, and Review of Business Information Systems. E-mail: jjwilliams@smu.edu.sg

Dr. Seaman is a Professor of Accounting at The Business School, Humber Institute of Technology \& Advanced Learning. He has several years of professional experience providing accounting and consulting services to private and public organizations. His research has investigated organization strategy, structure and process as they relate to management accounting and control systems. Currently, Dr Seaman is conducting research in Canadian organizations with the focus being governance, ethics, and management accounting systems and their relationship to the set of cognitive high reliability characteristics. E-mail: alfred.seaman@humber.ca (Corresponding author) 


\section{REFERENCES}

Albinger, H. S., \& Freeman, S. J. (2000). Corporate social performance and attractiveness as an employer to different job seeking populations. Journal of Business Ethics, 28, 243-253.

American Association for Public Opinion Research. (2013). Report of the AAPOR Task Force on non-probability sampling. Deerfield, IL: AAPOR.

Ashforth. B. E., \& Mael, F. (1989). Social identity theory and the organization. Academy of Management Review, 14, $20-39$.

Avey, J. B., Palanski, M. E., \& Walumbwa, F. O. (2011). When leadership goes unnoticed: The moderating role of follower selfesteem on the relationship between ethical leadership and follower behavior. Journal of Business Ethics, 98(4), 573 582.

Avey, J. B., Wernsing, T. S., \& Palanski, M. E. (2012). Exploring the process of ethical leadership: The mediating role of employee voice and psychological ownership. Journal of Business Ethics, 107(1), 21-34.

Avolio, B. J., \& Gardner, W. L. (2005). Authentic leadership development: Getting to the root of positive forms of leadership. Leadership Quarterly, 16, 315-338.

Bagozzi, R. P., \& Yi, Y. (1988). On the evaluation of structural equation models. Journal of the Academy of Marketing Science, 16(1), 74-94.

Bandura, A. (1986). Social foundations of thought and action. Englewood Cliffs, NJ: Prentice-Hall.

Bargh, J. A., \& Burrows, L. (1996). Automaticity of social behavior: Direct effects of trait construct and stereotype activation on action. Journal of Personality and Social Psychology, 71, 230-244.

Bass, B. M. (1985). Leadership and performance beyond expectations. New York: Free Press.

Bass, B. M. (1990). Bass \& Stodgill's handbook of leadership, 3rd Edition. New York: The Free Press.

Bass, B. M. (1998). Transformational leadership: industrial, military, and educational impact. Mahwah, NJ: Lawrence Erlbaum Associates.

Bass, B. M., \& Steidlmeier, P. (1999). Ethics, character, and authentic transformational leadership behavior. The Leadership Quarterly, 10, 181-217.

Bernstein, D. A., \& Nash, P. W. (2008). Essentials of psychology (4th ed.). Boston: Cengage Learning.

Bowen, H. P., \& Wiersema, M. F. (1999). Matching method to paradigm in strategy research: Limitations of cross-sectional analysis and some methodological alternatives. Strategic Management Journal, 20, 625-636.

Brown, T. J., \& Dacin, P. A. (1997). The company and the product: Corporate associations and consumer product responses. Journal of Marketing, 61, 68-84.

Brown, M., \& Treviño, L.K. (2006). Ethical leadership: A review and future directions. The Leadership Quarterly 17, $595-616$.

Brown, M. E., Treviño, L. K. \& Harrison D. A. (2005). Ethical leadership: A social learning perspective for construct development and testing. Organizational Behavior and Human Decision processes, 97(2), 117-134.

Brownell, P., \& Dunk, A. S. (1991). Task uncertainty and its interaction with budgetary participation and budget emphasis: some methodological issues and empirical investigation, Accounting Organizations and Society, 16 (8), 693-703.

Brownell, P., \& McInnes, M. (1986). Budgetary participation, motivation, and managerial performance. The Accounting Review, 61, 587-600.

Burns, J. M. (1978). Leadership. New York: Harper \& Row.

Butterfield, K. D., Treviño, L. K., \& Weaver, G. R. (2000). Moral awareness in business organizations: Influences of issuerelated and social context factors. Human Relations, 53, 981-1018.

Chenhall, R., \& Brownell, P. (1988). The effect of participative budgeting on job satisfaction and performance: Role ambiguity as an intervening variable. Accounting, Organizations and Society, 13 (3), 225-34.

Cronbach, L. J. (1951). Coefficient alpha and the internal structure of tests. Psychometrika, 16, 297-334.

Ciulla, J. B. (2004). Ethics and leadership effectiveness, in Antonakis, J., Cianciolo, A. T., \& Sternberg, R. J. (eds.). The nature of leadership. Thousand Oaks, CA: Sage Publications.

Dirks, K. T., \& Ferrin, D. L. (2002). Trust in leadership: Meta-Analytic findings and implications for research and practice. Journal of Applied Psychology, 87, 611-628.

Drucker, P. (1986). The practice of management. New York: Harper Collins Publishers.

Dutton, J. E., Dukerich, J. M., \& Harquail, J. M. (1994). Organizational images and member identification. Administrative Science Quarterly 39(2), 239-263.

Emerson, R. M. (1976). Social exchange theory. Annual Reviews, 2, 335-362.

Farooq, O., Payaud, M., Merunka, D. \& Valette-Florence, P. (2014). The impact of corporate social responsibility on organizational commitment: Exploring multiple mediation mechanisms, Journal of Business Ethics, 125, 563-580.

Fombrun, C. J., Gardberg, N. A., \& Barnett, M. L. (2000). Opportunity platforms and safety nets: Corporate citizenship and reputational risk. Business and Society Review, 105, 85-106.

Frey, B. F. (2000). The impact of moral intensity on decision making in a business context. Journal of Business Ethics, 26, 181195.

Glavas, A., \& Piderit, S. K. (2009). How does doing good matter? Effects of corporate citizenship on employees. Journal of Corporate Citizenship, 36, 51-70. 
Glavas, A., \& Godwin, N. (2013). Is the perception of 'goodness' good enough? Exploring the relationship between perceived corporate social responsibility and employee organizational identification. Journal of Business Ethics, 114, 15-27.

Greening, D. W., \& Turban, D. B. (2000). Corporate social performance as a competitive advantage in attracting a quality work force. Business and Society, 39, 254-280.

Greenleaf, R. K. (1977). Servant leadership. New York: Paulist Press.

Greenleaf, R. K. (1979). Seeker and servant. San Francisco: Jossey-Bass.

Harman, H. H. (1967). Modern factor analysis. Chicago, University of Chicago Press.

30. Hess, D., Rogovsky, N \& Dunfee, T. W. (2002). The next wave of corporate community involvement: Corporate social initiatives. California Management Review, 44(2), 110-125.

House, R. J., Rousseau, D. M., \& Thomas-Hunt, M. (1995). The meso paradigm: a framework for the integration of micro and macro organizational behavior. Research in Organizational Behavior, 17, 71-114.

International Federation of Accountants. (2009). International good practice guidance: evaluating and improving governance in organizations. New York.

Jones, T. M. (1991). Ethical decision making by individuals in organizations: An issue contingent model. Academy of Management Review, 16, 366-395.

Kacmar, K. M., Bachrach, D. G., Harris, K. J., \& Zivnuska, S. (2011). Fostering good citizenship through ethical leadership: Exploring the moderating role of gender and organizational politics. Journal of Applied Psychology, 96(3), 633-642.

Kanungo, R. N., \& Mendonca, M. (1996). Ethical dimensions of leadership. Thousand Oaks, CA: Sage.

Mahoney, T. A., Jerdee, T. H., \& Carroll, S. J. (1963). Development of managerial performance: A research approach. Cincinnati, OH: Southwestern Publishing Company.

Maignan, I., \& Ferrell, O. C. (2001). Corporate citizenship as a marketing instrument. European Journal of Marketing 35(3/4), 457-484.

Langer, E. J. (1997). The power of mindful learning. Reading, MA: Addison-Wesley.

Langer, E. J. (1989). Minding matters: The consequences of mindlessness-mindfulness, in Berkowitz, L. (ed.), Advances in experimental social psychology, 22, 137-173. San Diego, CA: Academic Press.

Lewis, P. \& Jacobs, T. O. (1992). Individual differences in strategic leadership capacity: a constructive/ developmental view in Phillips, R. L. \& Hunt, J. G. (eds.), Strategic Leadership: A Multi-Organizational-Level Perspective. Westport, CT: Quorum Books.

March, J. G., Sproull, L. S., \& Tamuz, M. (1991). Learning from samples of one or fewer. Organization Science, 2, 1-13.

May, D. R., \& Pauli, K. P. (2002). The role of moral intensity in ethical decision making: A review and investigation or moral recognition, evaluation and intention. Business and Society, 41, 84-117.

Mayer, D. M., Kuenzi, M., Greenbaum, R., Bardes, M., \& Salvadore, R. B. (2009). How low does ethical leadership flow? Test of a trickle-down model. Organizational Behavior and Human Decision Processes, 108(1), 1-13.

Mayer, D. M., Aquino, K, Greenbaum, R. L., \& Kuenzi, M. (2012). Who displays ethical leadership? An examination of antecedents and consequences of ethical leadership. Academy of Management Journal. 55(1), 151-171.

McWilliams, A., \& Siegel, D. (2001). Corporate social responsibility: A theory of the firm perspective. Academy of Management Review 26(1), 117-127.

Mendonca, M. (2001). Preparing for ethical leadership in organizations. Canadian Journal of Administrative Sciences, 18, 266276.

Mintzberg, H. (1973). The nature of managerial work. New York: Harper \& Row.

Mintzberg, H. (1975). The manager's job: Folklore and fact. Harvard Business Review, May, 12-20.

Morgeson, F. P., \& Humphrey, S. E. (2006). The work design questionnaire (WDQ): Developing and validating a comprehensive measure for assessing job design and the nature of work. Journal of Applied Psychology, 91(6), 1321-1339.

Morsing, M., \& Schultz, M. (2006). Corporate social responsibility communication: Stakeholder information, response and involvement strategies. Business Ethics: A European Review, 15(4), 323-338.

Murphy, P., Smith, J., \& Daley, J. (1992). Executive attitudes, organizational size and ethical issues: Perspectives on the service industry. Journal of Business Ethics, 11, 11-19.

Panwar, R., Rinne, T., Hansen, E., \& Juslin, H. (2006). Corporate responsibility: Balancing economic, environmental, and social issues in the forest products industry. Forest Products Journal, 56(2), 4-12.

Perez, A., \& Rodríguez del Bosque, I. (2013). Measuring CSR image: Three studies to develop and to validate a reliable measurement tool. Journal of Business Ethics, 118, 265-286.

Peterson, D. K. (2004). The relationship between perceptions of corporate citizenship and organizational commitment. Business \& Society 43(3), 296-319.

Piccolo, R. F., Greenbaum, R., den Hartog, D. N., \& Folger, R. (2010). The relationship between ethical leadership and core job characteristics. Journal of Organizational Behavior, 31(2/3), 259-278.

Podsakoff, P. M., MacKenzie, S. B, Lee, J. Y., \& Podsakoff, N. P. (2003). Common method biases in behavioral research: A critical review of the literature and recommended remedies. Journal of Applied Psychology, 88 (5), 879-903.

Rest, J. R. (1986). Moral development: Advances in research and theory. New York: Praeger.

Riordan, C. M., Gatewood, R. D., \& Bill, J. B. (1997). Corporate image: Employee reactions and implications for managing corporate social performance. Journal of Business Ethics, 16(4), 401-412. 
Roberts, K. H., Stout, S. K., \& Halpern, J. J. (1994). Decision dynamics in two high reliability military organizations, Management Science, 40, 614-624.

Rochlin, G. I. (1993). Defining 'high reliability’ organizations in practice: A taxonomy prologue, in Roberts, K. H. (ed.), New challenges to understanding organizations (11-32). New York: Free Press.

Rochlin, G. I. (1989). Informal organizational networking as a crisis avoidance strategy: U.S. naval flight operations as a case study, Industrial Crisis Quarterly, 3, 11-32.

Roth, G. (1997). Analysis of decision making in nuclear power plant emergencies: An investigation of aided decision making, in Zsambok, C. \& Klein, G., (eds.), Naturalistic decision making (175-182). NJ: Erlbaum, Mahwah.

Ruiz, P., Ruiz, C., \& Martinez, R. (2011). Improving the "leader-follower" relationship: Top manager or supervisor? The ethical leadership trickle-down effect of follower job response. Journal of Business Ethics, 99(4), 587-608.

Schermelleh-Engel, K., Moosbrugger, H., \& Müller, H. (2003). Evaluating the fit of structural equation models: Tests of significance and descriptive goodness-of-fit measures. Methods of Psychological Research Online, 8(2), 23-74.

Shin, Y. (2012). CEO ethical leadership, ethical climate, climate strength, and collective organizational citizenship behavior. Journal of Business Ethics, 108(3), 299-312.

Sitkin, S. B. (1992). Learning through failure: The strategy of small losses in Staw, B. M. \& Cummings, L. L. (eds.). Research in organizational behaviour, 14, 231-266. Greenwich, CT: JAI Press.

Toor, S.-R., \& Ofori, G. (2009). Ethical leadership: Examining the relationships with full range leadership model, employee outcomes and organizational culture. Journal of Business Ethics 90, 533-547.

Treviño, L. K., Hartman L. P., \& Brown, M. (2000). Moral person and moral manager: How executives develop a reputation for ethical leadership. California Management Review 42(4), 128-142.

Turker, D. (2009). How corporate social responsibility influences organizational commitment. Journal of Business Ethics, 89, 189-204.

Waddock, S. A. (2004). Parallel universes: Companies, academics, and the progress of CSR. Business and Society Review, 109, 5-42.

Waldman, D. A., Siegel, D. S., \& Javidan, M. (2006). Components of CEO transformational leadership and corporate social responsibility. Journal of Management Studies, 43(8), 1703-1725.

Weick, K. E., \& Sutcliffe, K. M. (2001). Managing the Unexpected. San Francisco, CA: Jossey-Bass.

Weick, K. E., Sutcliffe, K. M., \& Obstfeld, D. (1999). Organizing for high reliability: Processes of collective mindfulness, Research in Organizational Behavior, 21, 81-123.

Westrum, R. (1992). Cultures with requisite imagination, in J. A. Wise, Hopkin, D. \& Stager, P. (eds.). Human factors in safety critical systems (pp401-416). Berlin: Springer-Verlag.

Wildavsky, A. (1991). Searching for safety. New Brunswick: Transaction Books.

Williams, J. J., \& Seaman, A. E. (2010). Corporate governance and mindfulness: The impact of management accounting systems change. The Journal of Applied Business Research, 26(5), 1-17.

Wood, D. J., \& Jones, R. E. (1995). Stakeholder mismatching: A theoretical problem in empirical research on corporate social performance. International Journal of Organizational Analysis, 3(3), 229-267.

Wortman, M. S. (1982). Strategic management and changing leader-follower roles. Journal of Applied Behavioral Science, 18 , 371-383.

Zheng, Q., Luo, Y., \& Wang, S. L. (2014). Moral degradation, business ethics, and corporate social responsibility in a transitional economy. Journal of Business Ethics, 120, 405-4

\section{ENDNOTE}

\footnotetext{
${ }^{1}$ Reliability was checked with both Cronbach alpha and composite reliability in Table 1 because alpha tends to underestimate reliability unless the measures are tau-equivalent and may possibly overestimate the common latent variance. These issues are not apparent in the measures.
} 